\title{
The Properties of Arc-Sprayed Aluminum Coatings on Armor-Grade Steel
}

\author{
Marcin Adamiak ${ }^{1, *}$, Artur Czupryński ${ }^{2}$, Adam Kopyść ${ }^{1}$, Zbigniew Monica $^{3}$, \\ Małgorzata Olender ${ }^{3}$ and Aleksander Gwiazda ${ }^{3}$ \\ 1 Institute of Engineering Materials and Biomaterials, Faculty of Mechanical Engineering, Silesian University \\ of Technology, Konarskiego 18a, 44-100 Gliwice, Poland; adam.kopysc@gmail.com \\ 2 Department of Welding, Faculty of Mechanical Engineering, Silesian University of Technology, \\ Konarskiego 18a, 44-100 Gliwice, Poland; artur.czuprynski@polsl.pl \\ 3 Institute of Computer Integrated Manufacturing, Faculty of Mechanical Engineering, Silesian University of \\ Technology, Konarskiego 18a, 44-100 Gliwice, Poland; zbigniew.monica@polsl.pl (Z.M.); \\ malgorzata.olender@polsl.pl (M.O.); aleksander.gwiazda@polsl.pl (A.G.) \\ * Correspondence: marcin.adamiak@polsl.pl
}

Received: 3 December 2017; Accepted: 17 February 2018; Published: 22 February 2018

\begin{abstract}
This article presents the results of an examination of the properties of arc-sprayed aluminum on alloyed armor-grade steel. Thermal arc spraying was conducted with a EuTronic Arc Spray 4 wire arc sprayer. Aluminum wire $1.6 \mathrm{~mm}$ in diameter was used to produce dense, abrasion- and erosion-resistant coatings approx. $1.0 \mathrm{~mm}$ thick with and without nickel $/ 5 \%$ aluminum-buffered subcoating. Aluminum coatings were characterized in accordance with ASTM G 65-00 abrasion resistance test, ASTM G 76-95 erosion resistance tests, ASTM C 633-01 adhesion strength, HV0.1 hardness tests and metallographic analyses. Results demonstrate properties of arc-sprayed aluminum and aluminum-nickel material coatings that are especially promising in industrial applications where erosion-, abrasion- and corrosion-resistant coating properties are required.
\end{abstract}

Keywords: wire arc spraying; armor steel; erosion wear; adhesion strength; impact wear

\section{Introduction}

Methods of surface engineering such as thermal spraying have undergone many changes and developments in recent years, thanks in part to advances made in heat-source technology and newly developed coating materials [1-8]. Currently, around 70\% of industrial applications involving thermal spraying are used to produce new machinery parts or devices, which require a high finish and surface finish quality. The use of thermally sprayed coatings has not only increased the longevity of the protection features of steel assemblies against the effects of environmentally induced corrosion, but has also contributed to prolonging the service time of parts used in textile machinery, pump and mixer components, plastic injection molding machines, and to improving the reliability and durability of boiler components. Aluminum coatings are applied to structural components and devices made of steel, cast steel or cast iron, which are exposed to potentially corrosive environments in water, and atmospheres including exhaust gases regularly reaching $900{ }^{\circ} \mathrm{C}$ and periodically up to $1100{ }^{\circ} \mathrm{C}$. Steel alloys coated by this method show an increased temperature and hostile environment resistance, especially with respect to sulfur. Aluminum coatings are most commonly used in constructions with corrosivity categories of $\mathrm{C} 4$ and higher and at $\mathrm{pH} 4$ to 8 , providing significant life improvement over conventional barrier coatings. It can serve for a variety of marine, atmospheric and high-temperature applications [4-7]. 


\section{Experimental}

\subsection{Research Objectives}

The goal of this research was to develop the technical conditions of aluminum arc spraying using a TAFA 01T grade solid aluminum thermal spray wire deposited directly onto the surface of Armox $500 \mathrm{~T}$ armor-grade alloy steel and, in addition, on a buffered subcoating (composed of $95 \% \mathrm{Ni}+5 \% \mathrm{Al}$, solid thermal spray wire TAFA 75B BondArc grade). Technical assumption validity was confirmed by macroscopic and microscopic metallographic studies, erosion resistance, adhesion, hardness and coating testing.

\subsection{Materials and Equipment}

The arc spraying process was carried out in an upright position with a EuTronic Arc Spray 4 power source and a Gun 4 manual spray gun, Figure 1.

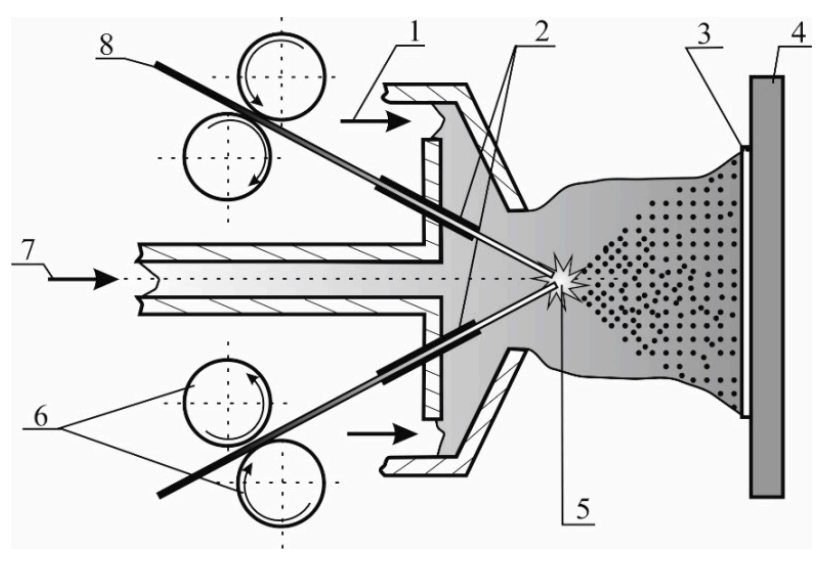

(a)

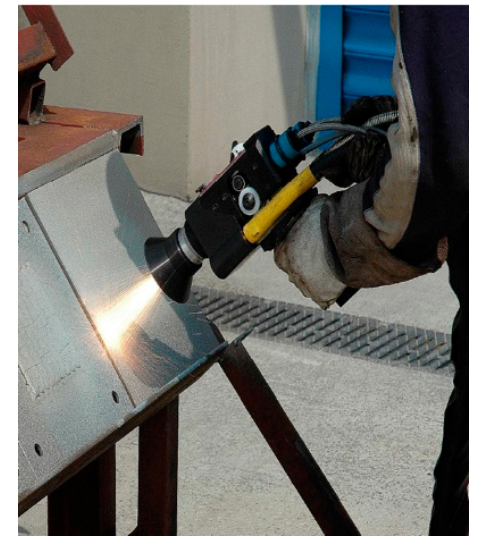

(b)

Figure 1. Spraying process: (a) scheme of wire arc spraying apparatus: 1 -compressed air; 2 -wire electric contact; 3-sprayed layer; 4-base metal; 5-electric arc; 6-wire feeder; 7—compressed air; 8 -welding wire; (b) photo of manual arc spray trial run.

The processed Armox 500T armor-grade alloy steel from SSAB was certified according to EN 10 204-3.1B, Table 1. Final surface preparation was done by abrasive blasting sheets prior to spraying with sharp-edged cast iron of $0.5-1.5 \mathrm{~mm}$ shot grain size in accordance with standard PN-EN ISO 2063-1:2017. Final surface roughness of the steel substrate after abrasive blasting was: $R_{\mathrm{a}}=12 \mu \mathrm{m}$, $R_{\mathrm{z}}=85 \mu \mathrm{m}$. The $300 \times 300 \times 8 \mathrm{~mm}^{3}$ steel plates were shot with pre-heated gas just before spraying and heated to about $40{ }^{\circ} \mathrm{C}$. During arc spraying, two types of Praxair TAFA solid wires were used; for the $0.1 \mathrm{~mm}$-thick buffered subcoating, a nickel/aluminum 75B BondArc grade with a diameter of $1.6 \mathrm{~mm}$ and, for the outer coating, a $0.8 \mathrm{~mm}$-thick $01 \mathrm{~T}$ grade aluminum wire with a diameter of $1.6 \mathrm{~mm}$.

Table 1. Chemical composition of Armox 500 T armor-grade alloy.

\begin{tabular}{cccccccccc}
\hline Plate Material & C & Si & Mn & P & S & Cr & Ni & Mo & B \\
\hline Armox 500 T & $\leq 0.32$ & $\leq 0.1 \pm 0.4$ & $\leq 1.2$ & $\leq 0.015$ & $\leq 0.01$ & $\leq 1.0$ & $\leq 1.8$ & $\leq 0.7$ & $\leq 0.005$ \\
\hline \multicolumn{10}{c}{ Note: Armox 500 T plate thickness $-8.0 \mathrm{~mm}}$.
\end{tabular}




\subsection{Arc Spraying Parameters}

Arc spraying samples were prepared in accordance with ISO 14923:2003 [9]. Optimal processing parameters are shown in Table 2. One trial sheet was made with and without binding nickel aluminate, from which the samples were subsequently cut. Testing in each case used 3 samples.

Table 2. Arc spraying parameters for buffered subcoating NiAl 95/5 and aluminum outer coating applied to Armox $500 \mathrm{~T}$.

\begin{tabular}{cc}
\hline Arc Spraying Parameters & Values \\
\hline Nozzle distance from material, mm & $150-200$ \\
Current, A & 120 \\
Arc Voltage, V & 34 \\
Spray gas pressure, bar & 4.2 \\
\hline
\end{tabular}

Note: NiAl buffered sub coating (75B BondArc) and aluminum outer coating (01T) were both applied with identical parameters.

\subsection{Metallographic Analysis of Coatings}

Microscopic and macroscopic studies were carried out in the cross-sectional plane and on the surface of samples (sample without buffered substrate and with nickel-aluminum buffered subcoating). Microscopic and macroscopic studies were conducted with an Olympus GX 71 light microscope. Surface analyses were carried out on an LEO 435 VP electron scanning microscope.

\subsection{Analysis of Coating Erosion Resistance}

The erosion resistance of aluminum arc sprayed coating were tested in accordance with ASTM G76-13 [10], as shown in Figure 2. Alumina $\left(\mathrm{Al}_{2} \mathrm{O}_{3}\right)$ powder was used as the erodent material with a particle diameter of $71 \mu \mathrm{m}$. The erodent particle velocity was $70 \pm 2 \mathrm{~m} / \mathrm{s}$, with efficiency of the erodent application set at $2.0 \pm 0.5 \mathrm{~g} / \mathrm{min}$ with a nozzle outlet distance from the test surface set $10 \mathrm{~mm}$. Erosion resistance tests were performed at attack angles of $90^{\circ}, 60^{\circ}$ and $30^{\circ}$.

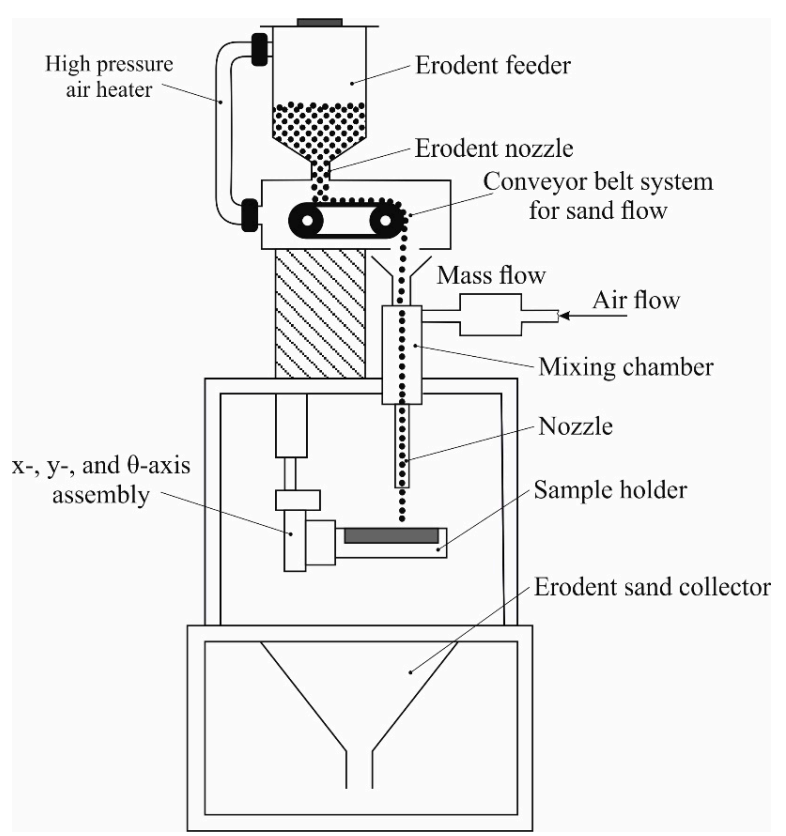

(a)

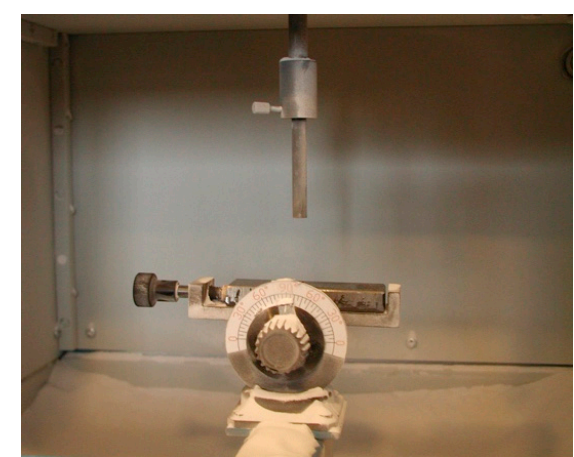

(b)

Figure 2. Erosion resistance test rig according to ASTM G 76-2: (a) a schematic view, (b) the interior view of the erosion measuring chamber. 


\subsection{Coating Hardness Measurements}

The hardness test of the aluminum shell and arc sub-cushion was done with a Vickers HV0.1 (Aluminum and Nickel Alloy Buffer Substrate) and HV1 (Substrate-Armox $500 \mathrm{~T}$ ) on a Micro-Hardness Tester 401MVD ${ }^{\mathrm{TM}}$. The test was carried out in accordance with ISO 6507-1.

\subsection{Analysis of Coating Adhesion Strength}

An attempt to determine the adhesion of the aluminum coating arc-sprayed to the steel substrate was carried out in accordance with ASTM C 633-01. For Armox $500 \mathrm{~T}$ steel plates subjected to arc-sprayed aluminum without buffering subcoating and with nickel-aluminum buffered subcoating, $40 \mathrm{~mm}$-diameter discs were cut. The sprayed samples were bound together using Henkel Loctite ${ }^{\circledR}$ $\mathrm{Hysol}^{\circledR} 3478$ A \& B Superior Metal Adhesive. Static testing was performed on a Zwick Z100 tensile test machine.

\subsection{Analysis of Coating Shock Resistance}

The impact resistance testing of aluminum arc-coated coatings on a steel substrate were carried out on a specially constructed test stand, patented PL 200880, Figure 3. The spray coating resistance criterion was the number of cracks and shattered shell fragments produced by repeated impact on the sprayed surface with a $20.0 \mathrm{~kg}$ carbon steel spatula tool freely released from a height of $1.02 \mathrm{~m}$ (impact energy $200 \mathrm{~J}$ ). The surface quality of the sprayed coating was evaluated on the basis of visual analysis at 50, 100, 150 and 200 impacts.

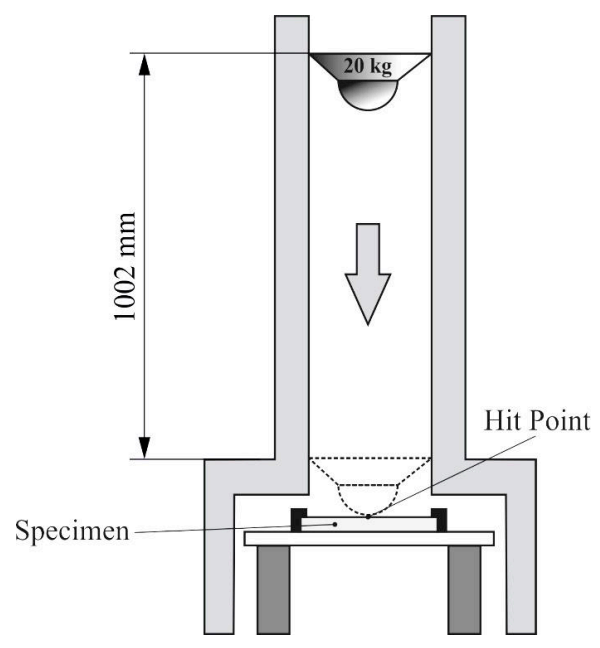

Figure 3. Stand for impact resistance tests on impact coatings reserved by Patent PL 200880.

\section{Results and Discussion}

As reported by the American Welding Society, pure aluminum and aluminum alloys are normally used in arc-spray processes, as they are the most outstanding coating materials in aggressive environments such as marine environments, under thermal insulation conditions, or for hot surfaces [11,12]. The advantages of aluminum coating originate from their passive film formation ability and, thus, their lower corrosion rate $[13,14]$. In this research, we additionally explored the potential of thermal arc-sprayed coatings without buffered subcoating and NiAl-buffered subcoating on Armox $500 \mathrm{~T}$ alloy steel with respect to erosion and impact loads.

\subsection{Metallographic and Roughness Test Results of Coatings}

The images of sprayed coatings' cross-sections are shown in Figure 4. The surface images are shown in Figure 5. Based on surface roughness testing, it was determined that the individual values 
for surface roughness of the aluminum coating without the binding subcoating were lower than those for the aluminum coating with nickel-aluminum subcoating (roughness difference of $R_{\mathrm{a}}=15 \mu \mathrm{m}$ ), Figure 6. Metallurgical microscopic and macroscopic analyses on the cross-sections and surfaces of the arc-sprayed samples with and without subcoating showed that the joining method of the coating to the substrate in the case of the arc-sprayed samples with and without binding subcoating expressed characteristic mechanical interlocking adhesion between the substrate and coating. Metallographic pictures show the deformed surface of the substrate by shot blasting, which makes the mechanical interlocking adhesion of the arc-sprayed coating possible. It was observed that the alumino-nickel subcoating shared a much more intricate bond with the aluminum substrate after shot blasting than with the steel substrate. Recess depth, projection height and feature widths are more favorable for coating adhesion on the surface of the nickel-aluminum subcoating than on the steel, and are denser by area, creating a more intricate mechanical interlocking adhesion surface. Metallographic analysis showed that the aluminum coating exhibited a porosity of 6-9\%. Cross sectional analysis of the structure showed that aluminum arc spraying, with and without binding nickel-aluminum subcoated surfaces, increased the occurrence of deposited molten drops of aluminum wire and spatter, and favored dynamic solidification of the aluminum coating.

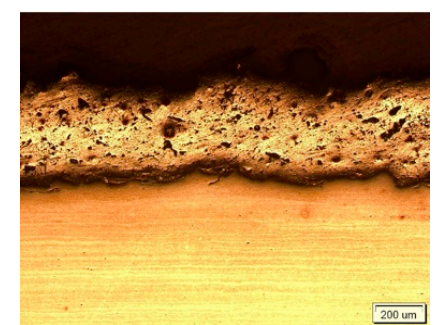

(a)

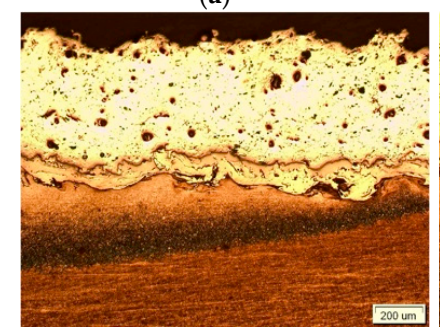

(d)

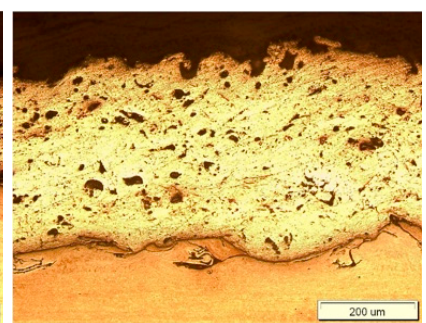

(b)

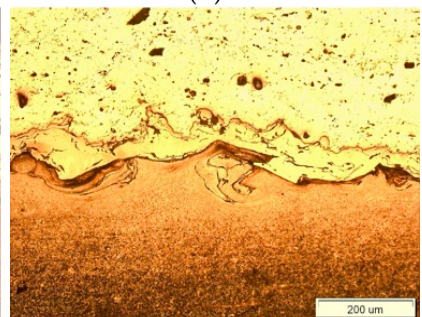

(e)

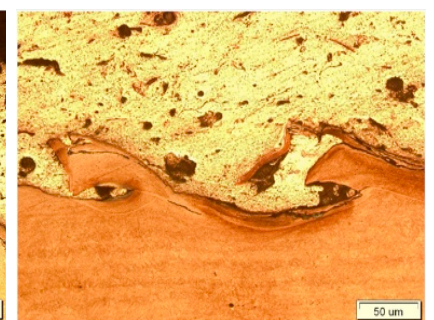

(c)

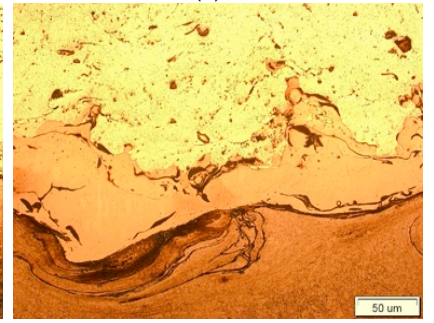

(f)

Figure 4. Images of the 01T grade wire arc-coated aluminum: $(\mathbf{a}-\mathbf{c})$ without buffering subcoating; $(\mathbf{d}-\mathbf{f})$ with wire-coated subcoating with $75 \mathrm{~B}$ Bond Arc grade, $\mathrm{Ni} / \mathrm{Al}$ alloy.

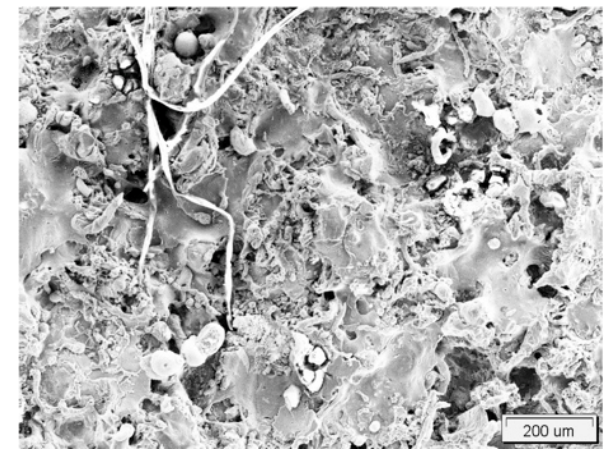

(a)

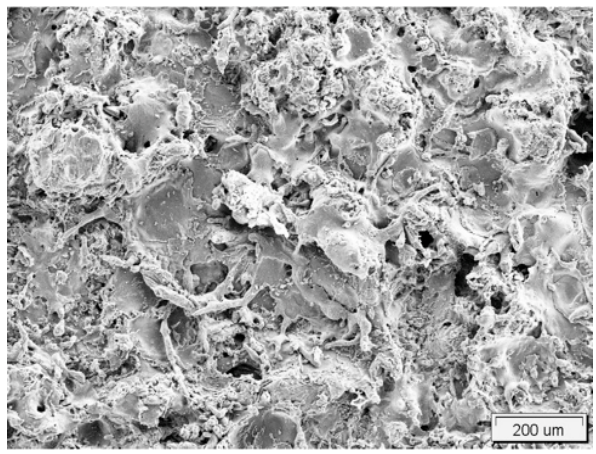

(b)

Figure 5. Images of the surface structure of wire 01T grade arc-sprayed aluminum: (a) without buffering subcoating; (b) buffered subcoating with 75B BondArc grade wire. 


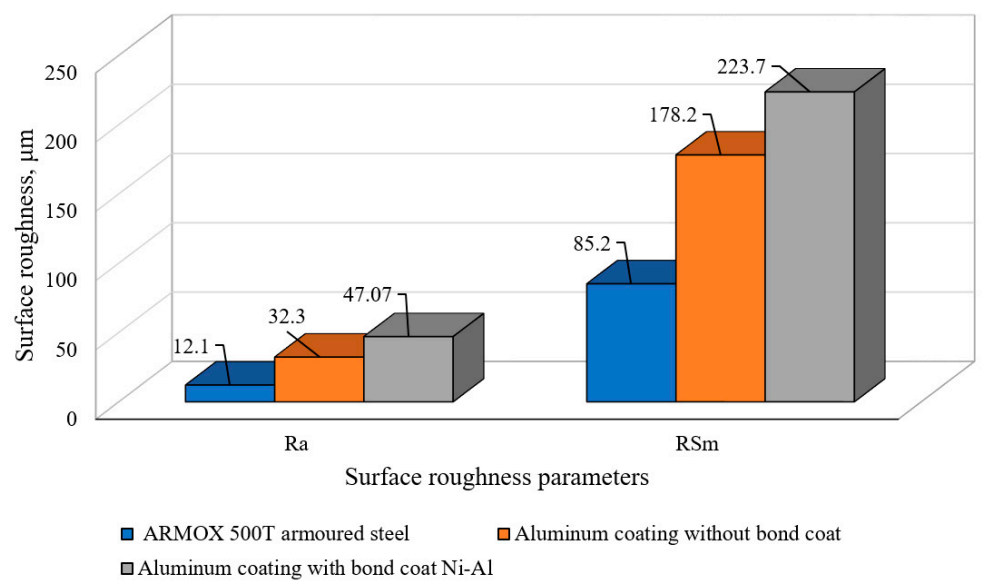

Figure 6. Surface roughness changes for Armox $500 \mathrm{~T}$ steel, $01 \mathrm{~T}$ grade wire arc-sprayed aluminum without buffering subcoating, and buffered subcoating with 75B BondArc grade wire.

\subsection{Coating Erosion Resistance Results}

The results of the erosion-resistant aluminum coating without buffered subcoating (PE1) and with the buffered aluminum sub-coating (PE2) are shown in Tables 3 and 4 and Figure 7. The 01T grade solid wire-based aluminum arc coating with nickel-aluminum 75B BondArc grade arc spray subcoating was observed to be most resistant to erosion with a particle angle of attack set to $60^{\circ}$. In this case, resistance to erosion was $\sim 55 \%$ lower than the aluminum arc-sprayed with $01 \mathrm{~T}$ grade solid wire without a binding subcoating. At a particle impact angle of $90^{\circ}$, the sample with the nickel-aluminum subcoating was observed to be $30 \%$ higher than ones without a binding subcoating; a similar outcome was observed for the $30^{\circ}$ attack angle-a higher resistance to erosion (about 35\%) than samples without nickel-aluminum binding subcoatings. The least resistant sample was observed to be the 01T aluminum-sprayed sample without subcoating at a $90^{\circ}$ attack angle; erosion resistance for this coating at maximum angle was $70 \%$ of the value for the nickel-aluminum subcoated aluminum samples.

Table 3. Summary of results obtained during the erosion test.

\begin{tabular}{|c|c|c|c|c|c|}
\hline $\begin{array}{c}\text { Erodent } \\
\text { Impact Angle } \\
\left({ }^{\circ}\right)\end{array}$ & $\begin{array}{c}\text { Sample } \\
\text { No./Time } \\
\text { (min) }\end{array}$ & $\begin{array}{l}\text { Mass Loss } \\
\quad(\mathrm{mg})\end{array}$ & $\begin{array}{l}\text { Volume Loss } \\
\qquad\left(\mathrm{mm}^{3}\right)\end{array}$ & $\begin{array}{l}\text { Erosion Rate } \\
\text { (mg/min) }\end{array}$ & $\begin{array}{l}\text { Resistance to } \\
\text { Erosion as per } \\
\text { ASTM G76 } \\
\left(0.001 \mathrm{~mm}^{3} / \mathrm{g}\right)\end{array}$ \\
\hline \multirow{2}{*}{90} & PE1/5 & 3.3 & 1.213 & 0.66 & 59.95 \\
\hline & $\mathrm{PE} 2 / 5$ & 2.6 & 0.836 & 0.42 & 42.50 \\
\hline \multirow{2}{*}{60} & PE1/5 & 3.8 & 1.397 & 0.76 & 68.99 \\
\hline & PE2/5 & 2.2 & 0.599 & 0.44 & 29.58 \\
\hline \multirow{2}{*}{30} & PE1/5 & 5.8 & 2.132 & 1.16 & 105.28 \\
\hline & PE2/5 & 5.2 & 1.417 & 0.82 & 69.98 \\
\hline
\end{tabular}

Notes: erosion rate $(\mathrm{mg} / \mathrm{min})=$ mass loss of sample $(\mathrm{mg})$ :exposure time $(\mathrm{min})$; Erosive wear resistance $\left(0.001 \mathrm{~mm}^{3} / \mathrm{g}\right)=$ volume loss of the sample $\left(\mathrm{mm}^{3}\right)$ :total mass of the erodent used in the test $(\mathrm{g})$; Density of aluminum spray coating $2.72\left(\mathrm{~g} / \mathrm{cm}^{3}\right)$, mass of erodent used $10.125(\mathrm{~g})$, test time $5(\mathrm{~min})$. 
Table 4. PE1 and PE2 samples after erosion test, comparison of erodent effect on the sample surfaces for each of the angles studied.

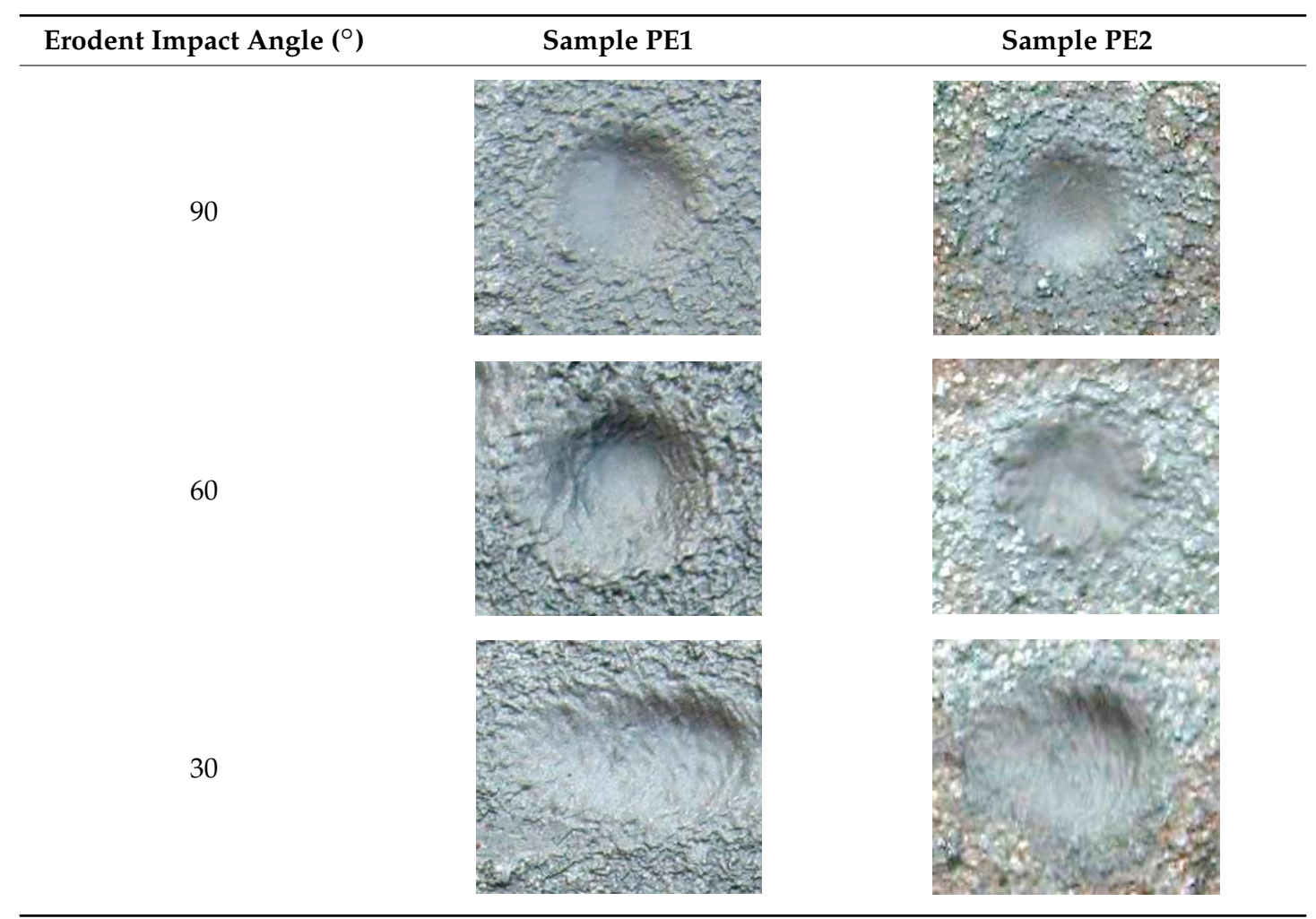

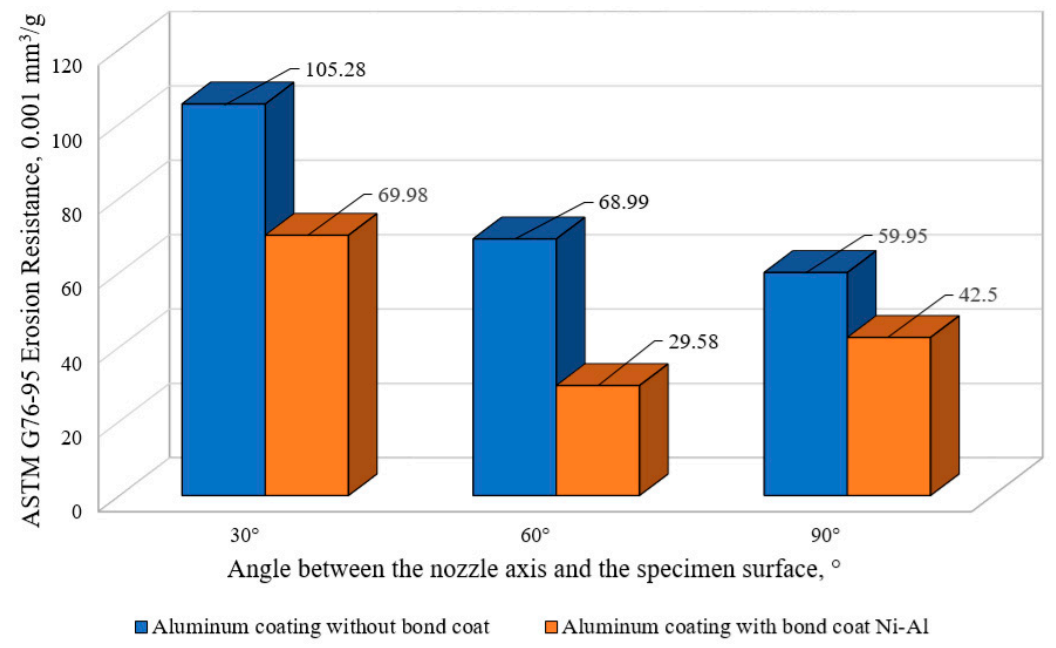

Figure 7. Results of erosion resistance tests for investigated materials and different erodent impact angles.

\subsection{Coating Hardness Testing Results}

Hardness measurements were made on the cross-section of sprayed coatings according to the scheme outlined in Table 5. Coating hardness test results indicated an increase in the hardness of the aluminum layer with $\mathrm{Ni} / \mathrm{Al}$ subcoating. The increase in hardness was approx. $14 \%$, and was associated with a decrease in porosity and an increase in the density of the coating. In addition, the formation of the intermediate layer influenced the state of stress in the arc-sprayed aluminum layer. 
Table 5. Results of hardness measurements measured on cross-section of arc-coated aluminum coatings on Armox 500 T alloy steel.

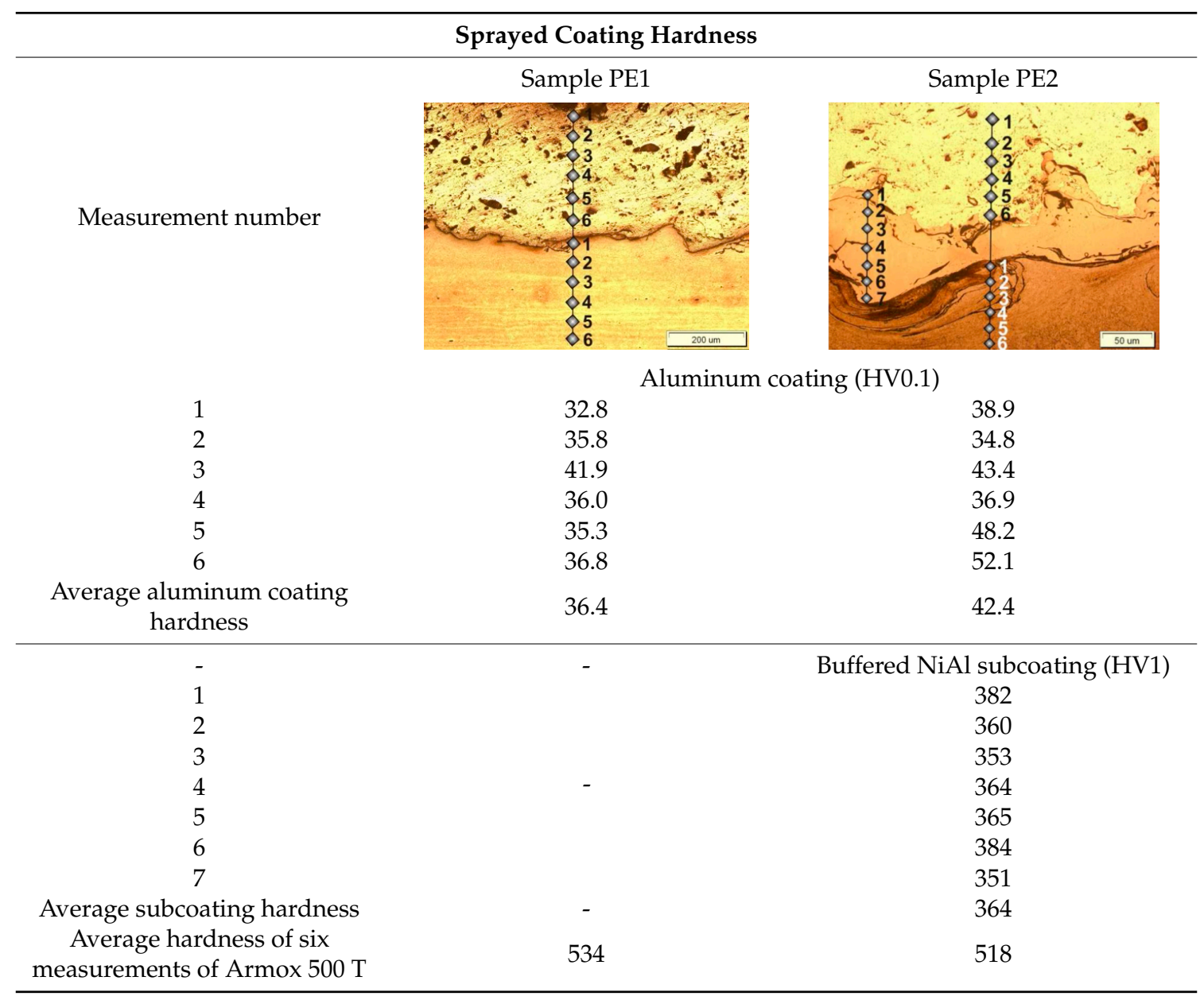

\subsection{Coating-Subcoating Adhesion Results}

The results of adhesion testing of aluminum without buffering subcoating (PE1) and aluminum coating with nickel-aluminum buffered subcoating (PE2) are presented in Table 6. As demonstrated in the study, the use of an intermediate layer causes an expected increase in adhesion of the coating to the substrate material. The increased adhesion of the coating is caused by the reduction of residual stresses in the sprayed layer and the increase in the integrity of the Ni/Al sublayer with a steel substrate. In addition, a greater degree of surface development improves the conditions for joining the $\mathrm{Al}$ coating with the sublayer. The use of an intermediate layer results in a $15 \%$ increase in the adhesion of the coatings produced.

Table 6. Summary of results obtained during the static tensile test of arc sprayed coatings.

\begin{tabular}{|c|c|c|c|c|c|}
\hline Sample & $\begin{array}{c}\text { Sample } \\
\text { No. }\end{array}$ & $\begin{array}{l}\text { Max Tensile } \\
\text { Force (kN) }\end{array}$ & $\begin{array}{l}\text { Surface Area } \\
\left(\mathrm{mm}^{2}\right)\end{array}$ & $\begin{array}{c}\text { Sprayed Coating } \\
\text { Adhesion } \\
\left(\mathrm{N} / \mathrm{mm}^{2}\right)\end{array}$ & $\begin{array}{l}\text { Average Coating } \\
\text { Adhesion } \\
\left(\mathrm{N} / \mathrm{mm}^{2}\right)\end{array}$ \\
\hline \multirow{4}{*}{ PE1 } & 1 & 14.8 & \multirow{6}{*}{1256.6} & 11.8 & \multirow{3}{*}{12.6} \\
\hline & 2 & 16.2 & & 12.9 & \\
\hline & 3 & 16.2 & & 12.9 & \\
\hline & 1 & 21.3 & & 17.0 & \multirow{3}{*}{16.0} \\
\hline \multirow[t]{2}{*}{ PE2 } & 2 & 19.6 & & 16.0 & \\
\hline & 3 & 19.1 & & 15.2 & \\
\hline
\end{tabular}




\subsection{Coating Shock Load Testing Results}

The results of resistance tests of the aluminum coating without buffered subcoating (PE1) and alumina-coated aluminum (PE2) coating on impact loads are shown in Figure 8. The impact load resistance analysis of aluminum coatings arc-sprayed on Armox $500 \mathrm{~T}$ grade steel did not reveal delamination or cracks in the coatings. The penetration impact testing conducted using ultraviolet light indicated that both the coating without the intermediate layer and with the $\mathrm{Ni} / \mathrm{Al}$ layer showed no crack network formation. In addition, macroscopic observations showed only plastic deformation of the coatings, with no clear difference due to the presence of the undercoat layer. The obtained results indicate good adhesion of the coatings to the substrate material, as well as their ability to undergo plastic deformation.

Coating with no subcoating PE1

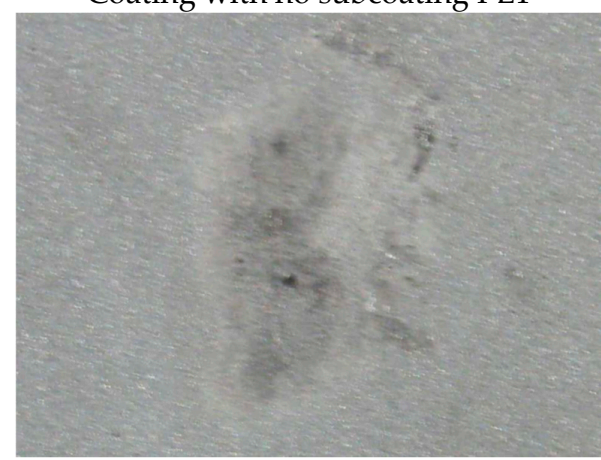

After 200 strokes

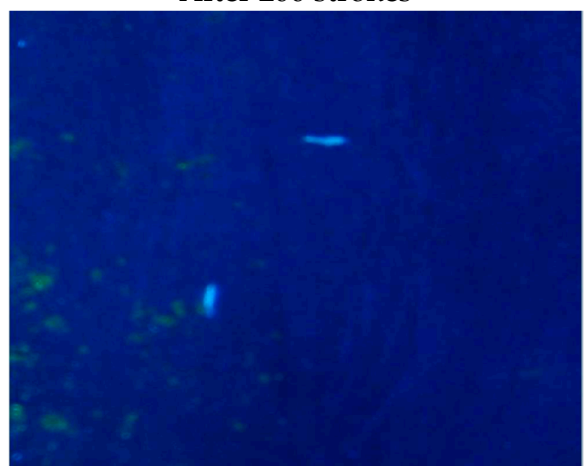

Image in UV, after 200 strokes

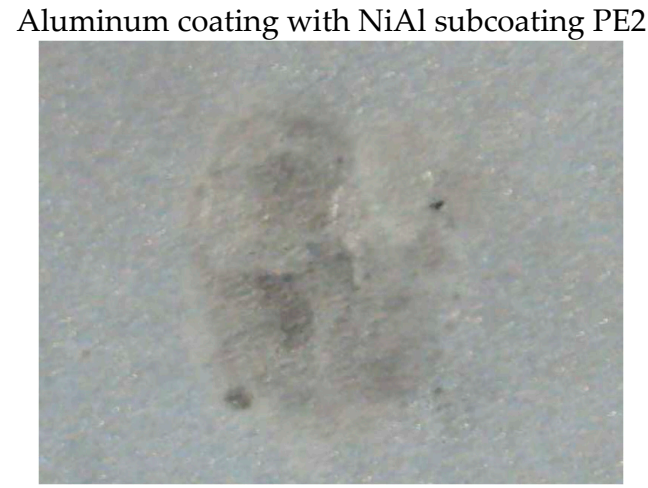

After 200 strokes

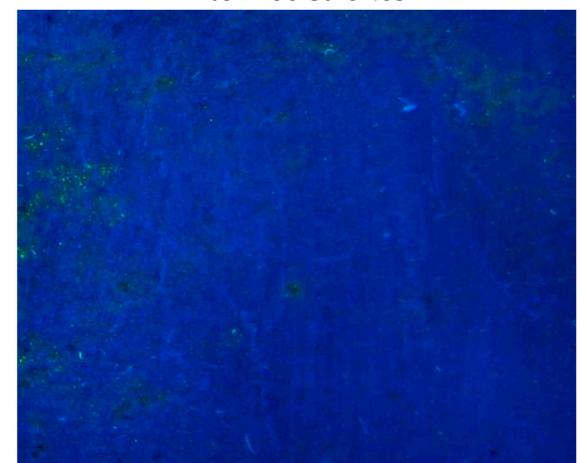

Image in UV after 200 strokes

Figure 8. View of aluminum arc-sprayed coatings on Armox $500 \mathrm{~T}$ steel after impact resistance tests (impact energy $200 \mathrm{~J}$ ).

\section{Conclusions}

Analysis of the results of the investigations into the development of the technical conditions of aluminum coatings with thicknesses of about $1.0 \mathrm{~mm}$, arc-sprayed from a TAFA 01T grade solid wire, both with no buffering subcoating and with a buffered aluminum coating sprayed with solid subcoating wire 75B BondArc grade, onto the Armox $500 \mathrm{~T}$ alloy steel has shown:

1. Arc-sprayed coatings without buffered subcoating and NiAl-buffered subcoating on Armox $500 \mathrm{~T}$ alloy steel provide high-quality spray coatings with a thickness of approximately $1.0 \mathrm{~mm}$.

2. The use of Nickel Alloy Buffer (NiAl 95/5) increases the adhesion of the aluminum coating by more than $4 \mathrm{MPa}$ as compared to aluminum sprayed directly onto the Armox $500 \mathrm{~T}$ steel substrate.

3. Much higher erosion wear resistance (about $55 \%$ at $60^{\circ}$ attack angle, and about $30 \%$ at erodent attack angles of $90^{\circ}$ and $30^{\circ}$ ) was exhibited by arc-coated aluminum on Armox 500 T alloy steel substrate using Nickel Alumina (NiAl 95/5)-buffered subcoating. 
4. Metallographic studies of spray coatings showed the mechanically interlocked mode of adhesion of the joint between the arc-sprayed coatings and the Armox $500 \mathrm{~T}$ alloy steel substrate.

5. Arc-sprayed aluminum coatings without buffering subcoating and with subcoating of nickel alumina have a mean hardness of $36.4 \mathrm{HV} 0.1$ and $42.4 \mathrm{HV} 0.1$, respectively. The mean hardness of the buffered nickel alumina coating was 364 HV1.6. The impact load resistance analysis of aluminum coatings arc-sprayed on Armox $500 \mathrm{~T}$ grade steel did not reveal delamination or cracks in the coatings for both of analyzed coatings type.

Author Contributions: Marcin Adamiak and Artur Czupryński conceived and designed the experiments; Artur Czupryński, Zbigniew Monica performed the experiments; Małgorzata Olender, Aleksander Gwiazda, Adam Kopyść analyzed the data; Adam Kopyść, Marcin Adamiak, Artur Czupryński wrote the paper.

Conflicts of Interest: The authors declare no conflict of interest.

\section{References}

1. Janicki, D. Laser cladding of Inconel 625-based composite coatings reinforced by porous chromium carbide particles. Opt. Laser Technol. 2017, 94, 6-14. [CrossRef]

2. Lisiecki, A.; Piwnik, J. Tribological characteristic of titanium alloy surface layers produced by diode laser gas nitriding. Arch. Metall. Mater. 2016, 61, 543-552. [CrossRef]

3. Janicki, D.; Musztyfaga, M.M. Direct diode laser cladding of Inconel 625/WC composite coatings. J. Mech. Eng. 2016, 62, 363-372. [CrossRef]

4. Lisiecki, A.; Kurc-Lisiecka, A. Erosion wear resistance of titanium-matrix composite Ti/TiN produced by diode-laser gas nitriding. Mater. Technol. 2017, 51, 29-34. [CrossRef]

5. Czupryński, A. Properties of $\mathrm{Al}_{2} \mathrm{O}_{3} / \mathrm{TiO}_{2}$ and $\mathrm{ZrO}_{2} / \mathrm{CaO}$ flame-sprayed coatings. Mater. Technol. 2017, 51, 205-212. [CrossRef]

6. Czupryński, A.; Górka, J.; Adamiak, M. Examining properties of arc sprayed nanostructured coatings. Metalurgija 2016, 55, 173-176.

7. Czupryński, A.; Górka, J.; Adamiak, M.; Tomiczek, B. Testing of flame sprayed $\mathrm{Al}_{2} \mathrm{O}_{3}$ matrix coatings containing $\mathrm{TiO}_{2}$. Arch. Metall. Mater. 2016, 61, 1363-1370. [CrossRef]

8. Dobrzański, L.; Adamiak, M.; D'Errico, G. Relationship between erosion resistance and the phase and chemical composition of PVD coatings deposited onto high-speed steel. J. Mater. Process. Technol. 1999, 92-93, 184-189. [CrossRef]

9. ISO 14923:2003. Thermal Spraying-Characterization and Testing of Thermally Sprayed Coatings; International Organization for Standardization: Geneva, Switzerland, 2003.

10. ASTM G76-13. Standard Test Method for Conducting Erosion Tests by Solid Particle Impingement Using Gas Jets; ASTM International: West Conshohocken, PA, USA, 2013.

11. Regina, M.H.; Pombo, R.; Paredes, R.S.C.; Wido, S.H.; Calixto, A. Comparison of aluminum coatings deposited by flame spray and by electric arc spray. Surf. Coat. Technol. 2007, 202, 172-179.

12. American Welding Society. Corrosion Test of Flame Sprayed Coated Steel-19 Years Report; American Welding Society: Miami, FL, USA, 2013.

13. Li, Y.; Liu, J.; Duan, J.; Hou, B. Thermally sprayed aluminium and zinc coatings for tidal zone cathodic protection of offshore platform pile leg. Mater. Perform. 2006, 45, 16-20.

14. Malek, M.H.A.; Saad, N.H.; Abas, S.K.; Nik Roselina, N.R.; Shah, N.M. Performance and microstructure analysis of $99.5 \%$ aluminium coating by thermal arc spray technique. Procedia Eng. 2013, 68, 558-565. [CrossRef]

(C) 2018 by the authors. Licensee MDPI, Basel, Switzerland. This article is an open access article distributed under the terms and conditions of the Creative Commons Attribution (CC BY) license (http:/ / creativecommons.org/licenses/by/4.0/). 